\title{
FOREWORD: DIATOM MICROGRAPHS OF THE CARPATHIAN REGION - ICONOGRAPHIA DIATOMOLOGICA CARPATHICA
}

\author{
Krisztina Buczkó \\ Department of Botany, Hungarian Natural History Museum, H-1431 Budapest, Pf. 137, Hungary; \\ buczko@bot.nhmus.hu
}

Buczkó, K. (2016): Foreword: diatom micrographs of the Carpathian Region - Iconographia Diatomologica Carpathica. - Studia bot. bung. 47(Suppl.): 7-8.

In the last couple of years - as other fields of photography - microphotography also benefited from the impressive, new advancements of digital technique. Diatom specialists profited from microphotography becoming cheap and easily accessible by making possible the publication of detailed documentation of diatom taxa regardless of size and resolution. However, there are significant differences in applying microphotography in different regions, where Hungary plays a pioneering role.

As for Hungary, the microphotographs have long history going back to $c a$ 150 years starting with the work of József Pantocsek (1846-1916), a prominent, well-known diatomist of the Carpathian Basin, with more than 1,300 described diatom taxa (BUCZKó 2012). In his collection more than 400 microphotographs are stored, the result of his pioneer search for the best ways to document the enormous diversity of diatoms. His experiments in microphotography were fruitful and as a photographer he won awards with his diatom pictures in 1884 on the National Exhibition. However, perhaps the photodocumentation turned out to be too expensive or time-consuming, Pantocsek turned back to drawing his specimens as documentation. Thus, most of his books and papers were exclusively published with tint-drawings (BUCZKó 2012).

Among the first microphotographers Oszvald Gallik must also be mentioned. He published pictures of diatoms of Lake Balaton, especially taxa belonging to the Cymbella genus (GALLIK 1926). However, the delineation of most diatoms remained documented by drawings for decades.

In Hungary, the Hungarian Geological Institute could support the high quality scanning and light microscope photodocumentation from the 1960s, till the 1990 s, resulting in the unusual situation that the fossil diatom flora is quite well documented (HAJós 1986), while the recent diatoms were rather neglected concerning modern illustrations. Moreover, the prominent diatomists of the time fo- 
cused exclusively on the taxonomy of a genus or group, and microphotographs have been published just of a restricted group, e.g. centric forms in KIss et al. (2012).

A new epoch in the global history of diatom research began in the 1980s, when the most of the newly described freshwater diatom flora relied on photographs rather than on drawings, largely due to the work of Krammer and LangeBertalot (e.g. 1986-1991). After these first volumes several richly illustrated books and monographs followed each other: the series of Bibliographia Diatomologica (ed. H. Lange-Bertalot), Iconographia Diatomologica (ed. H. Lange-Bertalot), and the Diatom Monographs, (ed. A. Witkowski).

Illustrated checklists of diatoms inhabiting lakes and rivers were still not available, until recently in the Carpathian region. The detailed diatom guide to the sodic lakes of Hungary of STENGER-KovÁCS and LENGYEL (2015) appeared after a long gap. Hopefully, we can regard their compilation as the opening volume of a new series that aims to document - based on modern photographic means - the diatom flora of the Carpathians. The present publication - as a new volume of the series - was constituted to be a guide for the diatoms of the Retezat Mountains. We hope that in the forthcoming years more diatom guides will be published of the Carpathian region contributing to the "Iconographia Diatomologica Carpathica" series. A new project entitled “CRYPTIC - Cryptogam's Traits in the Carpathians” (see at buczko.eu/Cryptic) also supports the realisation of this project (thanks to the National Research, Development and Innovation Office NKFI-6 119208).

We are confident that the "Iconographia Diatomologica Carpathica" series will provide a complete overview on the diatoms of the Carpathian region, and hopefully, as such, will be a substantial help for any diatomists working in the region or far away. The series will serve as a relevant source of information for non-diatom experts with scientific interest in the biogeography or morphological diversity of diatoms.

\section{REFERENCES}

Buczkó, K. (2012): The Pantocsek diatom and photomicrograph collection from 19th to the 21st century. - Beih. Nova Hedwigia 141: 535-546.

Gallik, O. (1926): Balatoni Diatomaceák. Diatomaceae ex lacu Balaton. - Archiv. Balaton. 1: $116-127$.

HAjós, M. (1986): A magyarországi miocén diatómás képződmények rétegtana. - Geol. Hung., ser. Palaeont. 49: 1-339.

Kiss, K., KLEE, R., Ector, L. and Ács, É. (2012): Centric diatoms of large rivers and tributaries in Hungary: morphology and biogeographic distribution. - Acta Bot. Croat. 71(2): 311-363. http://dx.doi.org/10.2478/v10184-011-0067-0

STENGER-KovÁcs, C. and LeNGYel, E. (2015): Taxonomical and distribution guide of diatoms in soda pans of Central Europe. - Studia bot. hung. 46(Suppl): 3-203.

http://dx.doi.org/10.17110/StudBot.2015.46.Suppl.3 